\title{
AKIBAT HUKUM TERHADAP PIHAK YANG TIDAK BERITIKAD BAIK DALAM PROSES JUAL BELI
}

\author{
Oleh : Norma ${ }^{1}$ dan Sukindar ${ }^{2}$ \\ ${ }^{1}$ Mahasiswa Fakultas Hukum Universitas 17 Agustus 1945 Samarinda \\ ${ }^{2}$ Dosen Fakultas Hukum Universitas 17 Agustus 1945 Samarinda
}

\begin{abstract}
Buying and selling is an activity carried out by two or more people to produce a mutual agreement, but there is often a sale and purchase which causes various problems. The existence of buying and selling with object agreements contain hidden defects. The situation is actually known consciously by the seller, but did not inform the buyer about it, so the buyer feels disadvantaged. Such events occur because of bad intentions or dishonest attitudes about information and the condition of an item. As a result of dishonest acts, the interests of one party have been violated. The problem raised in this paper is what the legal consequences are for parties who have no good intentions in the buying and selling process and what are the factors causing the parties to set aside good faith in the buying and selling process.

This type of research is normative juridical research, library research with the problem approach used in writing this thesis is the statute approach.

The results showed that with the enactment of legislation governing the buying and selling process of parties who do not have good intentions will cause legal consequences, namely the agreement becomes invalid and null and void and compensates for damages. But the reality on the ground, that the replacement of losses can be done if the parties agree. The factor causing the parties to set aside good faith in the buying and selling process is the lack of careful buyer or consumer to look for more detailed information related to the items they want to buy. While the seller or business actor, because of the opportunity to have bad intentions, in addition to that because of dishonesty.
\end{abstract}

Keywords: Legal Consequences, Not in Good Intention, Buying and Selling. 


\section{PENDAHULUAN}

\section{A. Latar Belakang}

Jual beli adalah bagian dari kegiatan perdagangan dengan tujuan untuk mencari keuntungan. Jual beli merupakan transaksi paling kuat dalam dunia perniagaan bahkan secara umum adalah kegiatan yang terpenting dalam aktivitas usaha. Kegiatan jual beli merupakan kegiatan yang berhubungan dengan kegiatan sosial karena adanya interaksi antara dua orang atau lebih. Adanya interaksi tersebut menimbulkan komunikasi sosial, yaitu antara penjual dan pembeli.

Pelaku utama dalam praktek jual beli adalah penjual dan pembeli itu sendiri. "Perkataan jual-beli menunjukkan bahwa dari satu pihak perbuatan dinamakan menjual, sedangkan dari pihak yang lain dinamakan membeli."1 Pihak penjual membutuhkan uang dan pembeli membutuhkan suatu barang, Jual beli merupakan kegiatan yang dilakukan oleh dua orang atau lebih untuk menghasilkan suatu kesepakatan bersama.

Lazimnya dalam proses jual beli selalu terjadi tawar menawar antara penjual dan pembeli terkait harga suatu barang hingga harga yang diinginkan disepakati. Karena tidak semua harga yang ditentukan oleh penjual disepakati oleh pembeli, sehingga terjadilah tawar menawar antar penjual dan pembeli. Peristiwa demikian, merupakan salah satu bentuk upaya untuk menciptakan bentuk-bentuk kesepakatan diantara mereka.

Manusia dalam mempertahankan kehidupanya diberi keleluasaan dalam mengambil sikap dan tindakan. Akibat adanya suatu alasan agar terpenuhi segala kebutuhan serta dipengaruhi oleh perkembangan dunia ekonomi, sangatlah wajar apabila masyarakat semakin banyak mengikatkan diri dengan masyarakat lain. Perikatan tersebut lahir dari adanya suatu perjanjian yang dilakukan oleh para pihak, dan selanjutnya terciptalah suatu hubungan hukum antara subjek hukum yang satu dengan subjek hukum yang lainnya, yaitu antara penjual dan pembeli. Menurut Pasal 1313 Kitab Undang-Undang Hukum Perdata mengatakan, bahwa "Suatu persetujuan adalah suatu perbuatan dimana satu orang atau lebih mengikatkan diri terhadap satu orang lain atau lebih."

Jual beli merupakan perjanjian timbal balik, pada dasarnya suatu perbuatan hukum dalam bentuk jual beli berawal dari suatu perbedaan atau ketidaksamaan kepentingan diantara para pihak. Satu pihak ingin melepaskan hak miliknya atas suatu barang dengan berharap diganti dengan sejumlah uang, sedangkan pihak yang lain ingin mendapatkan hak milik atas suatu barang tersebut dengan kesediaannya memberikan

Subekti, 2014, Aneka Perjanjian, Cet. XI, Penerbit PT Citra Aditya Bakti, Bandung, hal. 1. 
sejumlah uang kepada pemilik barang sebagai pengganti. Jual beli dianggap sudah terjadi antara kedua belah pihak saat baru saja mereka mencapai kesepakatan tentang barang dan harga, walaupun barang yang dimaksud belum beralih tangan dan harganya belum dibayar. Sebagaimana diketahui, hukum perjanjian menganut asas konsensualisme. "Artinya ialah hukum perjanjian dari B.W. itu menganut suatu asas bahwa untuk melahirkan perjanjian cukup dengan sepakat saja dan bahwa perjanjian itu (dan dengan demikian "perikatan" yang ditimbulkan karenanya) sudah dilahirkan pada saat detik tercapainya konsensus." " Jika belum sepakat maka belum ada ikatan hukum.

\section{B. Rumusan Masalah}

Dari hal-hal di atas maka peneliti ingin meneliti Akibat Hukum Terhadap Pihak Yang Tidak Beritikad Baik Dalam Proses Jual Beli dan Faktor Penyebab Para Pihak Mengesampingkan Itikad Baik Dalam Proses Jual Beli, Diharapkan hasil penelitian ini bermanfaat terhadap pengembangan ilmu hukum dan sebagai masukan bagi para penyelenggara negara dan yang terkait.

\section{KERANGKA DASAR TEORI}

\section{A. Teori Hukum}

Hans Kelsen mempunyai dasar-dasar penting pemikiran terhadap teori umum tentang hukum yang mana tujuan teori hukum yaitu sebagaimana setiap ilmu pengetahuan adalah untuk mengurangi kekacauan dan kemajemukan menjadi kesatuan, teori hukum merupakan ilmu pengetahuan mengenai hukum yang berlaku dan bukan mengenai hukum yang seharusnya, hukum adalah ilmu pengetahuan normatif dan bukan ilmu alam, teori hukum sebagai teori tentang norma-norma dan tidak ada kaitanya dengan daya kerja suatu norma-norma hukum itu sendiri, dan teori hukum itu adalah formal yaitu suatu teori tentang cara menata dan mengubah isi dengan cara yang khusus.

\section{B. Pengertian Perjanjian}

Perjanjian merupakan peristiwa yang melibatkan para pihak dengan saling berjanji untuk melaksanakan suatu perbuatan tertentu. Pengertian perjanjian diatur dalam Pasal 1313 Kitab Undang-Undang Hukum Perdata yaitu "Suatu persetujuan adalah suatu perbuatan dimana satu orang atau lebih mengikatkan diri terhadap satu orang lain atau

2 Ibid. hal. 3. 
lebih". Dari rumusan perjanjian tersebut dapat kita simpulkan bahwa unsur-unsur perjanjian itu adalah yang pertama, adanya para pihak, adanya persetujuan antar pihak-pihak tersebut. Kedua, adanya tujuan yang hendak dicapai. Ketiga, adanya prestasi yang akan dilaksanakan. Keempat, adanya bentuk tertentu, baik lisan maupun tulisan. Kelima, adanya syarat-syarat tertentu. Dalam suatu perjanjian adanya peristiwa dimana para pihak bersepakat mengenai hal-hal tertentu yang kemudian diperjanjikan dan diwajibkan bagi mereka untuk mentaati dan melaksanakannya sehingga perjanjian dapat melahirkan hubungan hukum bagi mereka yang membuatnya. Menurut Subekti, "perjanjian adalah peristiwa ketika seorang atau lebih berjanji melaksanakan perjanjian atau saling berjanji untuk melaksanakan suatu hal." "3 Selain itu, banyak pendapat lain yang berkembang terkait definisi perjanjian. Adapun menurut doktrin (teori lama) perjanjian adalah perbuatan hukum berdasarkan kata sepakat berdasarkan kata sepakat untuk menimbulkan akibat hukum. Sedangkan, menurut teori baru oleh Van Dunne, yang dimaksud dengan perjanjian adalah suatu hubungan hukum antara dua pihak atau lebih berdasarkan kata sepakat untuk menimbulkan akibat hukum.

\section{Objek dan Subjek Perjanjian}

Objek perjanjian merupakan prestasi yang dapat berupa memberikan sesuatu, untuk berbuat sesuatu, atau untuk tidak berbuat sesuatu. Oleh karena itu, barang yang menjadi objek dari suatu perjanjian haruslah cukup tertentu, setidaknya dapat ditentukan wujud dan jumlahnya, sehingga menjadi sah menurut hukum. Selain itu, yang menjadi objek perjanjian tidak boleh dari suatu sebab yang terlarang menurut perundang-undangan dan tidak bertentangan dengan ketertiban umum dan kesusilaan. Adapun yang dimaksud dengan subjek dalam perjanjian yaitu para pihak yang dapat diartikan sebagai pendukung hak dan kewajiban. Dalam hal ini kewajiban ditanggung oleh satu pihak dan hak atau manfaat yang didapat oleh pihak lain dengan menuntut dilaksanakannya suatu apa yang telah disanggupi dalam perjanjian. Pihakpihak itu disebut sebagai debitur dan kreditur.

3 Dedi Ismatullah, 2011, Hukum Perikatan, Cet. X, Penerbit CV PUSTAKA SETIA, Bandung, hal. 119. 


\section{Syarat Sah Perjanjian}

Menurut ketentuan Pasal 1320 Kitab Undang-Undang Hukum Perdata, terdapat syarat-syarat sahnya suatu perjanjian, yaitu :

1. Adanya Kesepakatan Diantara Para Pihak.

Kesepakatan merupakan suatu persesuaian pernyataan kehendak para pihak. Maksud dari kesepakatan ini adalah bahwa para pihak yang hendak mengadakan suatu perjanjian, harus terlebih dahulu bersepakat atau setuju mengenai hal-hal pokok dari perjanjian yang akan diadakan tersebut. Kemudian yang sesuai itu adalah pernyataanya, karena kehendak itu tidak dapat dilihat atau diketahui orang lain. kesepakatan tersebut tidak boleh disebabkan karena adanya kekhilafan, paksaan, dan penipuan, ketentuan ini dapat dilihat dalam Pasal 1321 Kitab Undang-Undah Hukum Perdata. "Pertanyaannya adalah "Kapan momentum terjadinya persesuaian pernyataan kehendak tersebut?" Ada empat teori yang menjawabhal ini, yaitu :"4

1) Teori Ucapan (uitingstheorie)

Menurut teori ini, kesepakatan (toesteming) terjadi pada saat pihak yang menerima penawaran menyatakan bahwa ia menerima penawaran. Jadi, dilihat dari pihak yang menerima, yaitu pada saat menjatuhkan pulpen untuk menyatakan menerima, kesepakatan sudah terjadi. Kelemahan teori ini adalah sangat teoritis karena menganggap terjadinya kesepakatan acara otomatis.

2) Teori Pengiriman (verzendtheorie)

Menurut teori ini, kesepakatan terjadi apabila pihak yang menerima penawaran mengirimkan telegram. Kritik terhadap teori ini, bagaimana hal itu bias dilakukan? Bisa saja, walaupun sudah dikirim, tidak diketahui oleh pihak yang menawarkan teori ini juga sangat teoritis, menganggap terjadinya kesepakatan secara otomatis.

3) Teori Pengetahuan (vernemingstheorie)

Teori pengetahuan berpendapat bahwa kesepakatan terjadinya apabila pihak yang menawarkan itu mengetahui adanya acceptatie (penerimaan), tetapi penerimaan itu belum diterimanya (tidak diketahui secara langsung).

4) Teori Penerimaan (ontvangstheorie)

Menurut teori ini, toesteming terjadi pada saat pihak yang menawarkan menerima langsung jawaban dari pihak lawan.

\footnotetext{
4 R. Joni Bambang, 2013, Hukum Ketenagakerjaan, Penerbit Pustaka Setia, Bandung, hal. 87.
} 
Ketentuan dalam hukum positif Belanda, pula diikuti yurisprudensi, ataupun doktrin, teori yang dianut adalah teori pengetahuan (vernemingstheorie) dengan sedikit koreksi dari ontvangstheorie (teori penerimaan). "Maksudnya, penerapan teori pengetahuan tidak secara mutlak, sebab, lalu lintas hukum menghendaki gerak cepat dan tidak menghendaki formalitas yang kaku, sehingga vernemingstheorie yang dianut." Karena apabila harus menunggu sampai mengetahui secara langsung bahwa adanya jawaban dari pihak lain (ontvangstheorie), membutuhkan waktu yang lama.

2. Kecakapan Bertindak

Kecakapan bertindak merupakan suatu kecakapan atau kemampuan untuk melakukan perbuata hukum yang mana perbuatan hukum tersebut akan menimbulkan akibat hukum. Dalam hal ini haruslah orang-orang yang cakap dan berwenang untuk melakukan perbuatan hukum, sebagaimana yang ditentukan oleh undang-undang. artinya orang tersebut menurut hukum dapat melakukan perbuatan hukum. Seperti orang yang dewasa, tidak dibawah pengampuan, dan tidak cacat mental.

3. Suatu Hal Tertentu Atau Adanya Objek Perjanjian

Suatu hal tertentu yang berarti perjanjian harus menentukan jenis objek yang akan diperjanjikan. Barang yang menjadi objek perjanjian haruslah tertentu, setidaknya haruslah ditentukan jenisnya, sedangkan jumlahnya tidak perlu ditentukan, asalkan nantinya dapat ditentukan atau diperhitungkan. Ketentuan tersebut dapat dilihat dalam Pasal 1333 Kitab Undang-Undang Hukum Perdata. Objek perjanjian dikenal sebagai prestasi yang merupakan kewajiban debitur dan hak kreditur. Prestasi dapat berupa perbuatan untuk memberikan sesuatu, berbuat sesuatu, atau tidak berbuat sesuatu.

4. Suatu Sebab Atau Kausa Yang Halal

"Suatu sebab yang halal merupakan syarat yang keempat untuk sahnya perjanjian. Mengenai syarat ini Pasal 1335 BW menyatakan bahwa suatu perjanjian tanpa sebab, atau yang telah dibuat karena suatu sebab yang terlarang, tidak mempunyai kekuatan." ${ }^{\text {" }}$ Yang artinya bahwa perjanjian yang dibuat tidak boleh bertentangan dengan perundang-undangan, kesusilaan, dan ketertiban umum.

Ibid., hal. 163.

Wirjono Prodjodikoro, 2004, Asas-asas Hukum Perjanjian, Cet. VII, Sumur Bandung, Bandung, hlm. 211. 
Syarat 1 dan 2 disebut dengan syarat-syarat subjektif karena dalam hal ini mengenai subjek atau pihak-pihak yang mengadakan perjanjian, sedangkan syarat $\mathrm{c}$ dan $\mathrm{d}$ disebut dengan syarat-syarat objektif adapun dalam hal ini mengenai objek perjanjiannya. Konsekuensi yang harus ditanggung apabila satu atau lebih syarat sahnya suatu perjanjian tidak terpenuhi maka perjanjian itu akan, yaitu :

"Batal demi hukum (nietig, null and void). Dalam hal ini, kapan pun perjanjian tersebut dianggap tidak pernah sah dan dianggap tidak pernah ada, dalam hal ini jika tidak terpenuhi syarat objektif dalam pasal $1320 \mathrm{KUH}$ Perdata Indonesia. Dapat dibatalkan (vernietigerbaar, voidable). Dalam hal ini, perjanjian tersebut baru dianggap tidak sah, jika perjanjian tersebut dibatalkan oleh yang berkepentingan, dalam hal ini jika tidak terpenuhinya syarat subjektif dalam pasal 1320 KUH Perdata Indonesia. Perjanjian tidak dapat dilaksanakan (unenforceable). Dalam hal ini, merupakan perjanjian yang tidak dilaksanakan adalah jika perjanjian tersebut tidak begitu saja batal, tetapi juga tidak dapat dilaksanakan, tetapi perjanjian tersebut masih mempunyai status hukum tertentu. Dikenakan sanksi administratif. Dalam hal ini, ada syarat dalam perjanjian, yang apabila syarat tersebut tidak dipenuhi tidak mengakibatkan batalnya perjanjian tersebut, melainkan hanya mengakibatkan salah satu pihak atau kedua belah pihak terkena semacam sanksi administratif."

\section{E. Tinjauan Umum Tentang Jual Beli}

Jual beli diatur dalam Pasal 1457 Kitab Undang-Undang Hukum Perdata. Yang dimaksud dengan jual beli adalah "suatu persetujuan, dengan mana pihak satu mengikatkan dirinya untuk menyerahkan suatu kebendaan, dan pihak lain untuk membayar harga yang dijanjikan. Esensi dari definisi ini penyerahan benda dan membayar harga.",

Perkataan jual beli memperlihatkan bahwa adanya pihak yang satu karena perbuatanya disebut penjual dan pihak lainnya yang karena perbuatannya disebut pembeli. masing-masing mereka adalah pasangan subjek hukum yang dapat memiliki hak dan kewajiban. Pihak pembeli berhak menerima barang dan berkewajiban menyerahkan uang sebagai penganti barang. Sedangkan, pihak penjual berhak menerima uang sebagai penganti barang dan berkewajiban menyerahkan barang yang telah dibeli.

7 Munir Fuady, 2015, Konsep Hukum Perdata, PT Raja Grafindo Persada, Jakarta, hal. 186-187.

8 Salim H.S, 2015, Hukum Kontrak Teori dan Teknik Penyusunan Kontrak, Cet. XI, Penerbit Sinar Grafika, Jakarta, hal. 48. 
Jadi, subjek hukum merupakan pendukung hak dan kewajiban. Oleh karena itu, maka subjek tersebut memiliki kewenangan untuk bertindank menurut hukum. Adapun para pihak atau subjek hukum yang dikenal dalam hukum perlindungan konsumen yaitu pelaku usaha dan konsumen. Adapun pengertian konsumen menurut Undang-Undang Nomor 8 Tahun 1999 Tentang Hukum Perlindungan Konsumen dalam Pasal 1 ayat (2) yakni:

"Konsumen adalah setiap orang pemakai barang dan atau jasa yang tersedia dalam masyarakat, baik bagi kepentingan diri sendiri, keluarga, orang lain, maupun makhluk hidup lain dan tidak diperdagangkan."

Menurut ketentuan dalam Pasal 1 angka 3 Undang-Undang Nomor 8 Tahun 1999 Tentang Hukum Perlindungan Konsumen disebutkan pelaku usaha adalah "setiap orang perorangan atau badan usaha, baik yang berbentuk badan hukum maupun bukan badan hukum yang di dirikan dan berkedudukan atau melakukan kegiatan dalam wilayah hukum Republik Indonesia, baik sendiri maupun bersamasama melalui perjanjian menyelenggarakan kegiatan usaha dalam bidang ekonomi."9

Jual beli tidak akan terjadi tanpa adanya objek dalam jual beli tersebut. Maka, penting pula keberadaan suatu objek hukum, yaitu segala sesuatu yang berguna bagi subyek hukum dan dapat menjadi pokok dari suatu hubungan hukum, karena dapat dikuasai oleh subjek hukum. Objek dalam jual beli adalah semua benda bergerak dan tidak bergerak, baik menurut tumpukan, berat, ukuran, dan timbangannya. Dalam jual beli tidak diperkenankan menjual belikan benda tau barang orang lain, benda yang tidak diperkenankan oleh undang-undang, bertentangan dengan ketertiban umum dan kesusilaan. Apabila hal itu tetap dilakukan maka jual beli itu batal demi hukum.

Jual beli bertujuan untuk mengalihkan hak milik atas kebendaan yang dijual. Pengalihan hak milik tersebut dilakukan dengan penyerahan objek jual beli oleh penjual kepada pembeli. Penyerahan dimaksud, menurut Pasal 1459 Kitab Undang-Undang Hukum Perdata menegaskan bahwa "Hak milik atas barang yang dijual tidak pindah kepada pembeli selama barang itu belum diserahkan menurut Pasal 612, 613 dan 616." Berkaitan dengan hal penyerahan, sesungguhnya telah diatur yang sifatnya mutlak dan tidak dapat ditawar-tawar oleh siapapun juga. Hal itu tertuang dalam ketentuan Pasal 584 Kitab Undang-Undang Hukum Perdata yang menegaskan bahwa

\footnotetext{
9 Ibid,. hal. 41.
} 
"Hak milik atas sesuatu kebendaan tak dapat diperoleh dengan cara lain, melainkan dengan pemilikan, karena perlekatan; karena daluwarsa, karena perwarisan, baik menurut undang-undang, maupun menurut surat wasiat, dan karena penunjukan atau penyerahan berdasar atas suatu peristiwa perdata untuk memindahkan hak milik, dilakukan oleh seorang yang berhak berbuat bebas terhadap kebendaan itu.

Jual beli yang telah dilakukan dan telah mengikat para pihak karena kata sepakat terkait suatu benda beserta harganya oleh para pihak, tidak dapat dibatalkan secara sepihak. Hal itu, berdasarkan ketentuan Pasal 1338 ayat (1) dan ayat (2) Kitab Undang-Undang Hukum Perdata menyatakan bahwa "Semua persetujuan yang dibuat secara sah berlaku sebagai undang-undang bagi meraka yang membuatnya. Persetujuan itu tidak dapat ditarik kembali selain dengan kesepakatan kedua belah pihak, atau karena alasan-alasan yang ditentukan oleh undang-undang."

\section{F. Kewajiban dan Hak Penjual}

Kewajiban sebagai suatu prestasi yang merupakan perwujudan dari janji yang diikrarkan oleh para pihak. Intinya kewajiban itu sebenarnya dibuat kemudian dipikul sendiri ke pundak masing-masing pihak dalam suatu perjanjian jual beli secara sadar dan sengaja. Oleh Pasal 1473 Kitab Undang-Undang Hukum Perdata diamanatkan bahwa "Penjual wajib menyatakan dengan jelas, untuk apa ia mengikatkan dirinya, janji yang tidak jelas dan dapat diartikan dalam berbagai pengertian, harus ditafsirkan untuk kerugiannya."

Kewajiban sebagai suatu prestasi yang merupakan perwujudan dari janji yang diikrarkan oleh para pihak. Intinya kewajiban itu sebenarnya dibuat kemudian dipikul sendiri ke pundak masing-masing pihak dalam suatu perjanjian jual beli secara sadar dan sengaja. Oleh Pasal 1473 Kitab Undang-Undang Hukum Perdata diamanatkan bahwa "Penjual wajib menyatakan dengan jelas, untuk apa ia mengikatkan dirinya, janji yang tidak jelas dan dapat diartikan dalam berbagai pengertian, harus ditafsirkan untuk kerugiannya."

Hak penjual dalam pelaksanaan perjanjian jual beli yaitu menerima pembayaran dari harga yang telah disepakati oleh pembeli mengenai barang yang diperjual belikan. Menurut Pasal 1513 kitab Undang-Undanh Hukum Perdata menjelaskan bahwa kewajiban utam pembeli yaitu membayar harga pembelian barang sebagaimana yang telah ditetapkan dalam persetujuan, hal tersebut merupakan hak yang harus diterima oleh penjual. Adapun pula hak penjual ketika persesuaian kehendak sampai pelaksanaan perjanjian yaitu mendapatkan itikad baik dari pihak pembeli. Selain itu, telah termaktub dalam Pasal 1517 Kitab Undang-Undang Hukum Perdata, apabila pembeli tidak membayar harga pembelian 
tersebut, maka penjual dapat menuntut pembatalan perjanjian menurut ketentuan-ketentuan Pasal 1266 dan 1267.

\section{G. Kewajiban dan Hak Pembeli}

Pembeli merupakan rekan seperikatan penjual dalam proses jual beli, pihak pembeli memikul kewajiban sebagaimana penjual. Namaun jika dibandingkan, ketentuan yang menentukan apa saja kewajiban pembeli relatif tidak terlalu banyak ketimbang kewajiban yang harus dipikul penjual. Hal ini karena pembeli tidak banyak terkait dengan hal yang menyangkut hak milik suatu benda yang dijadikan objek jual beli. Selain nantinya pembeli menerima benda itu saat penjual melakukan penyerahan.

Kewajiban utama pembeli adalah membayar harga pembelian pada waktu dan di tempat yang ditetapkan dalam persetujuan." Yang dimaksud dengan harga tersebut adalah sejumlah uang untuk pembayaran. Sesungguhnya hal yang demikian tidak dijelaskan dalam suatu pasal undang-undang, namun sudah secara langsung termaktub dalam pengertian jual beli. Sebab, jika harga yang dimaksud itu berupa barang, maka akan merubah perjanjiannya menjadi tukar-menukar, atau kalau harga itu berupa suatu jasa, perjanjiannya akan berubah menjadi perjanjian kerja, dan begitu seterusnya.

Hak pembeli dalam pelaksanaan jual beli terdapat dalam Pasal 1481 Kitab Undang-Undang Hukum Perdata yaitu mengenai hak menerima barang pada waktu penjualan. Pembeli menerima barang dengan dilakukannya penyerahan oleh pihak penjual ke dalam kekuasaan dan kepemilikan pihak pembeli. Adapun pula hak pembeli ketika persesuaian kehendak hingga pelaksanaan perjanjian tersebut yaitu memperoleh itikad baik dari pihak penjual.

\section{H. Pengertian Itikad Baik}

Itikad baik sesungguhnya telah termaktub dalam Pasal 1338 ayat (3) Kitab Undang-Undang Hukum Perdata yang berbunyi : "Persetujuan harus dilaksanakan dengan itikad baik". Ketentuan tersebut mempersoalkan pada taraf pelaksanaan suatu perjanjian. Sebenarnya suatu itikad baik merupakan pengertian yang abstrak. Dan kalaupun seseorang mengerti apa itu itikad baik, orang itu masih sulit merumuskannya.

Subekti merumuskan itikad baik dengan pengertian bahwa "itikad baik diwaktu membuat suatu perjanjian berarti kejujuran, orang yang beritikad baik menaruh kepercayaan sepenuhnya kepada pihak lawan, yang dianggap jujur dan tidak menyembunyikan sesuatu yang buruk di 
kemudian hari akan menimbulkan kesulitan-kesulitan." ${ }^{\prime 10}$ Secara sederhana yang dimaksud dengan itikad baik dalam suatu perjanjian dapat diartikan, bahwa suatu perjanjian hendaklah dilaksanakan dengan kejujuran dan bersih, sehingga dalam pelaksanaannya nanti akan tercermin kepastian hukum dan rasa adil bagi para pihak yang terikat dalam perjanjian tersebut.

\section{Pengertian Cacat Tersembunyi}

Cacat tersembunyi merupakan suatu keadaan dimana barang atau objek perjanjian yang tidak dalam keadaan atau tidak sebagaimana yang diharapkan oleh pihak yang menginginkan barang atau objek tersebut. Adapun barang yang dapat dikatakan mengandung cacat apabila memenuhi kriteria-kriteria sebagai berikut:

"Pertama, cacat produk merupakan cacat yang tidak sesuai dengan harapan konsumen dalam pembelian barang. Kedua, cacat peringatan adalah cacat yang ditemukan pada suatu barang yang tidak dilengkapi dengan peringatan untuk penggunaan tertentu yang dapat membahayakan konsumennya. Ketiga, cacat desain adalah cacat yang terjadi pada saat suatu barang dalam proses persiapan seperti pada saat mendesain dan mengkontruksi. ${ }^{11}$

Akibat dari keadaan yang demikian menimbulkan kerugian. Tidak ada suatu pengertian yang secara eksplisit mendefinisikan tentang cacat tersembunyi, namun sebagaimana diatur dalam Pasal 1504 Kitab Undang-Undang Hukum Perdata bahwa :

"Penjual harus menanggung barang itu terhadap cacat tersembunyi, yang sedemikian rupa sehingga barang itu tidak dapat digunakan untuk tujuan yang dimaksud, atau yang demikian mengurangi pemakaian, sehingga seandainya pembeli mengetahui cacat itu, ia sama sekali tidak akan membelinya atau tidak akan membelinya dengan harga yang kurang."

10 Samuel M.P Hutabarat, 2010, Penawaran Dan Penerimaan Dalam Hukum Perjanjian, Penerbit Grasindo, Jakarta, hal. 45.

11 Celina Tri Siwi Kristiyanti, 2011, Hukum Perlindungan Konsumen, Cet. III, Penerbit Sinar Grafika, Jakarta, hal.103. 


\section{METODE PENELITIAN}

Metode penelitian pada penelitian ini adalah kualitatif yaitu menjelaskan dengan kata-kata berupa narasi dengan membeberkan data yang ditemukan selama penelitian baik diperpustakaan, pengamatan dan wawancara. Lokasi penelitian di kota Samarinda, Tepatnya Kantor Toko Ruanggadged_id dan UD Berkah Besama Motor di Kota Samarinda. Yang menjadi sampel yaitu sebanyak $25 \%$.

\section{IV.PEMBAHASAN}

Pengaturan dalam hal konsumen yang tidak beritikad baik juga termuat dalam Undang-Undang Perlindungn Konsumen dimana hak pelaku usaha dalam Pasal 6 huruf (b) mengatakan bahwa "Hak untuk mendapat perlindungan hukum dari tindakan konsumen yang beritikad tidak baik". Secara khusus Undang-Undang Perlindungan Konsumen telah mengatur bahwa baik konsumen maupun pelaku usaha memiliki kewajiban yaitu harus beritikad baik, sebagaimana diatur dalam Pasal 5 huruf (b) dan Pasal 7 huruf (a). Terhadap pihak yang dirugikan dalam proses jual beli Pasal 19 Undang-Undang Perlindungan Konsumen, pelaku usaha bertanggung jawab memberikan ganti rugi atas kerusakan, pencemaran, dan atau kerugian konsumen akibat mengkonsumsi barang dan atau jasa yang dihasilkan atau diperdagangkan. Pemberian ganti rugi tidak menghapuskan kemungkinan adanya tuntutan pidana berdasarkan pembuktian lebih lanjut mengenai adanya unsur kesalahan. Pemberian ganti rugi dilaksanakan dalam tenggang waktu tujuh hari setelah transaksi. Ganti rugi tidak berlaku apabila pelaku usaha dapat membutkitan bahwa kesalahan tersebut merupakan kesalahan konsumen. Penyelesaian sengketa dapat dilakukan diluar pengadilan maupun melalui pengadilan.

Berdasarkan hasil wawancara dari kedua narasumber yaitu wawancara pertama dengan pemilik toko Ruang Gadget_id Bapak Muhammad Mariadi pada tanggal 2 April 2020, dan wawancara kedua dengan pemilik showroom (tempat memamerkan produk) mobil bekas UD. BERKAH BERSAMA MOTOR dengan Bapak Rudhye Negara pada tanggal 3 April 2020. Masing-masing narasumber mengatakan bahwa ketika adanya perbuatan yang mengakibatkan kerugian bagi para pihak dalam proses jual beli karena adanya itikad tidak baik, tentunya kembali kepada bentuk-bentuk kesepakatan yang telah mereka perjanjikan yaitu mengenai ganti rugi, pengembalian barang, pemotongan harga, dan lain sebagainya. Hal tersebut apabila memang diperjanjikan oleh para pihak. Perjanjian jual beli tersebut berdasarkan asas konsensualisme yang berarti 
kesepakatan mengenai barang dan harga, begitu para pihak setuju maka lahirnya jual beli yang sah. asas ini menjiwai aturan dalam hukum perdata.

Berdasarkan hasil wawancara pertama dengan pemilik toko Ruang Gadget_id Bapak Muhammad Mariadi pada tanggal 2 April 2020 mengatakan bahwa "Misalnya saya sebagai pembeli pertama tidak menanyakan apakah ada minus-minus, kekurangan, atau cacat pada barang tersebut. Juga karena tidak memahami tentang HP (handphone) biasanya dalam hal mereka berani mengambil barang tersebut tanpa tahu informasi barang dengan jelas. Padahal informasi itu penting, jangan sampai dikemudian waktu merasa dirugikan. Dan menurut narasumber, jika penjual menjual barang dengan kondisi cacat atau ada minus tanpa memberitahukan informasi itu padahal dia mengetahuinya, hal itu dapat disebabkan karena kebutuhan penjual dan jika persediaan barang memang ada dan peminatnya juga ada, maka barang itu akan dilepas. Karena sebagai pedagang barang yang diperdagangkan harus terjual semua, tetapi seharusnya mereka jujur apabila tidak jujur berarti hanya ingin meraup keuntungan pribadinya saja."

Hasil wawancara kedua penulis dengan pemilik showroom (tempat memamerkan produk) mobil bekas UD. BERKAH BERSAMA MOTOR dengan Bapak Rudhye Negara pada tanggal 3 April 2020 mengatakan bahwa "Menurut narasumber, bahwa mereka tidak bisa memfonis orang atau pembeli tersebut tidak beritikad baik. Namun ada indikasi pembeli tersebut tidak beritikad baik sudah bisa kita ketahui sejak awal. Misalnya ketika melihat mobil, melakukan pengecekan terhadap mobil, kemudian di hari berikutnya membuat janji untuk melakukan transaksi diluar showroom kami tidak melayani hal tersebut. Adapun juga dalam hal pembayaran baik cash (tunai) maupun Kredit (cicilan) apabila pembeli tidak beritikad baik untuk melakukan pembayaran. Faktor penyebab bisa karena kurangnya pengetahuan untuk beritikad baik ataupun karena keadaan. Namun apapun itu hak dan kewajiban harus tetap dilaksanakan. Adapun beberapa penjual terkadang juga tidak beritikad baik karena adanya peluang untuk melakukan hal tersebut dan juga karena tidak jujur, misalnya dalam hal menjual mobil bekas yang terdapat cacat tersembunyi, kebanyakan penjual itu tidak memberi tahu hal itu walaupun dia mengetahui benar adanya cacat itu. tentu hal ini akan merugikan terlebih jika harganya pun tidak sesuai dengan kondisi barang."

Berdasarkan hasil wawancara dari kedua narasumber diatas maka penulis menyimpulkan bahwa yang menjadi faktor penyebab para pihak mengesampingkan itikad baik dalam proses jual beli yaitu kurangnya ketelitian pembeli atau konsumen untuk mencari informasi secara lebih detail terkait barang yang diperjual belikan dan tidak beritikad baik karena tidak melakukan pembayaran sebagaimana mestinya. Adapun terhadap 
penjual atau pelaku usaha umumnya mengesampingkan itikad baik karena adanya peluang untuk beritikad buruk, tuntutan untuk menjual barang atau produk yang mereka punya tanpa memperhatikan layak atau tidaknya suatu produk atau barang yang diperdagangkan. Selain itu, di sebabkan oleh ketidak jujuran penjual atau pelaku usaha agar meraup keuntungan baik dari segi penjualan ataupun membeli barang tersebut yang selanjutnya akan dijual kembali.

\section{PENUTUP}

\section{A. Kesimpulan}

1. Ancaman hukuman Akibat hukum apabila adanya itikad tidak baik para pihak yaitu ketika barang yang menjadi objek perjanjian bertentangan dengan ketentuan hukum, maka akan mengakibatkan perjanjian diantara para pihak tidak sah dan menyebabkan perjanjian batal demi hukum. Undang-Undang Perlindungan Konsumen sejatinya telah mengatur bagi pelaku usaha untuk mendapat perlindungan hukum dari tindakan konsumen yang beritikad tidak baik dan terhadap pihak yaitu konsumen yang dirugikan dalam proses jual beli pelaku usaha bertanggung jawab memberikan ganti rugi, penyelesaian sengketa dapat dilakukan diluar maupun melalui pengadilan. Namun, kenyataannya dilapangan para pihak yang merasa dirugikan akibat mengesampingkan itikad baik dalam proses jual beli akan kembali lagi kepada perjanjian yang telah mereka sepakati bersama, salah satunya yaitu terkait penggantian kerugian. Hal tersebut apabila memang diperjanjikan oleh para pihak.

2. Faktor yang menjadi faktor penyebab para pihak mengesampingkan itikad baik dalam proses jual beli yaitu kurangnya ketelitian pembeli atau konsumen untuk mencari informasi secara lebih detail terkait barang yang ingin mereka beli dan tidak beritikad baik karena tidak melakukan pembayaran sebagaimana mestinya. Penjual atau pelaku usaha umumnya mengesampingkan itikad baik karena adanya peluang untuk beritikad buruk, tuntutan untuk menjual barang atau produk yang mereka punya tanpa memperhatikan layak atau tidaknya suatu produk atau barang yang diperdagangkan. Selain itu, di sebabkan oleh ketidak jujuran penjual atau pelaku usaha agar meraup keuntungan baik dari segi penjualan ataupun membeli barang tersebut yang selanjutnya akan dijual kembali. 


\section{B. Saran-Saran}

1. Sebaiknya pemerintah perlu lebih mengiatkan sosialisasi dan pembinaan kepada masyarakat secara umum terkait pentingnya beritikad baik dalam proses jual beli agar hal-hal yang tidak diingingkan dapat dihindarkan. Adapun terhadap masyarakat umum yang dapat berperan sebagai pihak penjual ataupun pihak pembeli seyogyanya dalam proses jual beli didasari oleh itikad baik mulai dari tahap kesepakatan kehendak hingga pelaksanaan jual beli tersebut dengan memperhatikan dan melaksanakan kewajiban-kewajiban masing-masing pihak, sehingga nantinya akan terlaksana jual beli yang diharapkan dengan terpenuhinya segala yang menjadi hak-hak para pihak.

2. Serta terhadap penjual atau pelaku usaha hendaknya memenuhi seluruh hak-hak konsumen dan disarankan agar memberikan informasi yang benar, jelas, dan rinci atas barang atau objek yang ia hendak jual kepada pembeli atau konsumen.

\section{DAFTAR PUSTAKA}

Dedi Ismatullah, 2011, Hukum Perikatan, Cet. X, Penerbit CV PUSTAKA SETIA, Bandung.

Kartini Muljadi dan Gunawan Widjaja, 2010, Perikatan Yang Lahir dari Perjanjian, Cet. V, RajaGrafindo Persada, Jakarta.

Mukti Fajar dan Yulianto Achmad, 2013, Dualisme Penelitian Normatif dan Empiris, Cet. II, Penerbit Pustaka Pelajar, Yogyakarta.

Munir Fuady, 2015, Hukum Kontrak Buku Kesatu, Cet. IV , Penerbit PT Citra Aditya Bakti, Bandung.

Munir Fuady, 2015, Konsep Hukum Perdata, PT Raja Grafindo Persada, Jakarta.

P.N.H Simajuntak, 2015, Hukum Perdata Indonesia, Cet. I, Penerbit Kencana, Jakarta.

R. Joni Bambang, 2013, Hukum Ketenagakerjaan, Penerbit Pustaka Setia, Bandung.

Salim H.S, 2015, Hukum Kontrak Teori dan Teknik Penyusunan Kontrak, Cet. XI, Penerbit Sinar Grafika, Jakarta.

Shidarta, 2006, Hukum Perlindungan konsumen Indonesia, Edisi Revisi, Penerbit PT Grasindo, Jakarta.

Wirjono Prodjodikoro, 2004, Asas-asas Hukum Perjanjian, Cet. VII, Sumur Bandung, Bandung. 
Undang-Undang Dasar Negara Republik Indonesia Tahun 1945.

Kitab Undang-undang Hukum Perdata (KUHP)

Undang-Undang Republik Indonesia Nomor 8 Tahun 1999 Tentang Perlindungan Konsumen. 